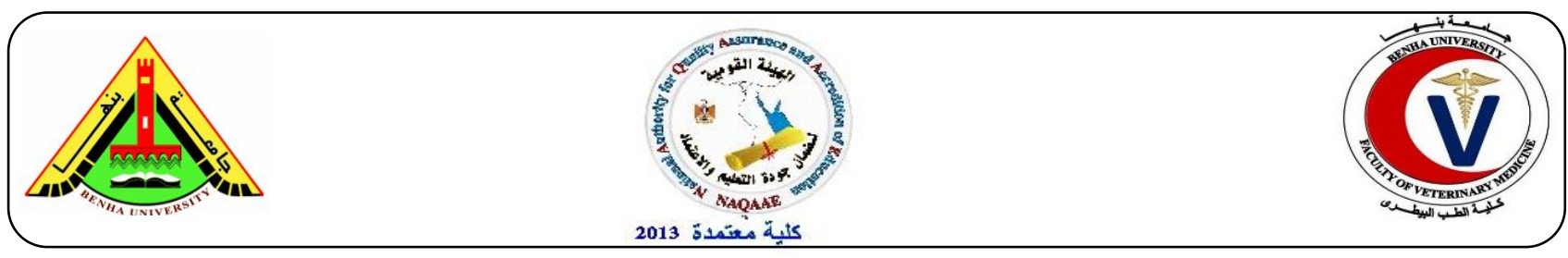

\title{
Study on Aflatoxin Residues in some Meat Products and their Control by Probiotics
}

\author{
Hemmat M. Ibrahim ${ }^{1}$, Reham A. Amin ${ }^{1}$, Khalid S. Tolba ${ }^{2}$ and Amira A. Elokle ${ }^{2}$ \\ ${ }^{1}$ Food Hygiene and Control Department, Faculty of Veterinary Medicine - Benha University Egypt. \\ ${ }^{2}$ Animal Health Research Institute, Agriculture Research center,Dokki, Egypt.
}

A B S T R A C T

Mould not only causes deterioration of food and feed, but also adversely affects the health of man and animals since it is capable of producing toxic metabolites known as mycotoxins causing food poisoning and liver cancer. Thus, creating awareness about aflatoxin residues and their control in food is of great importance for public health. From this point of view, this study was designed to evaluate total aflatoxin residues and their control by probiotics. A total of 100 random samples of meat products represented by beef burger, sausage, minced meat and luncheon ( 25 of each), were collected from different super markets in Cairo governorate. The obtained results revealed that the total aflatoxin residues were higher in luncheon $(1.63 \pm 0.32 \mathrm{ppb})$ with the highest prevalence $(88 \%)$. Also, the effect of probiotics on the reduction of aflatoxin residues in naturally contaminated minced meat sample was studied. Two probiotic strains (Lactobacillus acidophilus and Bifidobacteriumlactis) could be able to cause gradual reduction in total aflatoxin residues up to $88 \%$ and $98.3 \%$, respectively of total aflatoxin residues within 8 days of experiment.

Keywords: Aflatoxin residues, AFT, AFB1, Lactobacillus acidophilus, Bifidobacteriumlactis and ELISA.

(http://www.bvmj.bu.edu.eg)

(BVMJ-34(1): 232-241, 2018)

\section{INTRODUCTION}

Meat products are considered favourable foods as they are easy to buy, fast to cook, delicious to eat, so they are the first choice for many people all over the world (Heinz and Hautzinger, 2007). On the other hand, meat products may be contaminated with moulds as they are widely distributed in nature and may contaminate meat and meat products through several ways. The environment inside slaughter houses and butcher-shops including walls, floors, utensils, hides and the intestinal contents of food animals, as well as tables, knives and refrigerators are considered as the main sources of fungal contamination of meat. Mycotoxinogenic moulds such as Aspergillus, Fusarium and Penicillium play undesirable role in the deterioration of the marketable quality and hygiene of food stuffs by synthesizing highly toxic metabolites known as mycotoxins. The occurrence of mycotoxigenic moulds in food is potentially dangerous for public health and also 
constitutes a major economic problem (Dalie et al., 2010).

Aflatoxins are highly toxic fungal secondary metabolites that if ingested can cause a variety of adverse effects on both human and animal. Aflatoxins are carcinogenic compounds produced predominantly by certain species of Aspergillus, especially A. flavus and $A$. parasiticus. These fungi can grow on a wide variety of foods and feeds under favorable temperature and humidity. Contamination by aflatoxins can take place at any point along the food chain (Giray et al., 2007). Aflatoxins are common contaminants of foods, particularly in the staple diet of many countries, and they are categorized as class 1 A human carcinogen by International Agency for Research on Cancer (IARC, 2002). They have immunosuppressive, mutagenic, teratogenic and carcinogenic effects, especially on the liver. Food and feedstuff contaminated with aflatoxins (AFTs) is a serious health problem for man and animals, especially in developing countries Ghazvini et al. (2016).

A variety of physical, chemical and biological methods have been developed for decontamination and control of aflatoxins from contaminated goods and feeds (Morteza et al., 2013). The probiotic bacteria are living microorganisms which upon ingestion in certain numbers exert health benefits beyond inherent basic nutrition. The empirical use of microorganisms and/or their natural products for the preservation of foods (bio preservation) has been a common practice in the history of mankind (Ross et al., 2002).

There is a great chance for reducing the presence of AFs in food products through the utilization of certain types of nonpathogenic bacteria such as the group of LAB. Also, utilization of LAB as a food supplement or probiotic products preventing the absorption of AFB1 in human and animal bodies as they have the ability for binding and isolating AFB1(Farber et al., 2000 and Hamidi et al.,2013).

Moreover, several studies have suggested that the antimutagenic and anticarcinogenic properties of probiotic bacteria can be attributed to their ability to non-covalently bind hazardous chemical compounds such as aflatoxins in the colon.

Lactic acid bacteria work as biological absorbents that prevent aflatoxins transfer to the intestinal tract of man and animals. Lactobacilli especially are relatively well studied and provide noticeable possibilities in binding of aflatoxin $\mathrm{B}_{1}$ and $\mathrm{M}_{1}$ in food (Sara et al. 2015).

This study was designed to determine the total aflatoxin residues in the examined meat products and to investigate the ability of Lactobacillus acidophilus and Bifidobacteriumlactis to reduce total aflatoxin residues in naturally contaminated minced meat sample.

\section{MATERIALS AND METHODS}

\subsection{Collection of samples:}

A total of 100 random samples of meat products represented by beef burger, sausage, minced meat and luncheon (25 of each), were collected from different super markets in Cairo governorate. Each sample weighed about $100 \mathrm{~g}$ and aseptically transferred without delay, in an insulated ice box to the laboratory and subjected to mycological examination and aflatoxin detection.

\subsection{Estimation of total aflatoxins (Sahar et al., 2013)}

The quantitative analysis of total aflatoxins was determined through a competetive direct enzyme linked immunosorbent assay (CDELISA) method. The method based on accurate monitoring of mycotoxins. The 
veratox test kits (Neogen Crop., Lansing, MI. USK. Approved by the AOAC research institute (certificate No 950702) and the USDA-GIPSA (2008-011) were used. The analysis was done according to the manufacturer's instructions. Concentration of aflatoxins was calculated by $\log / \log$ it software Awarness Technology Inc. (Anonymous, 2000 and Stoloff et al.,1999).

Calculation: For quantitative results, absorbance values obtained for the standards and the samples were divided by the absorbance value of the first standard (zero standard) and multiplied by 100 (percentage maximum absorbance). Therefore, the zero standard is thus made equal to $100 \%$ and the absorbance values are quoted in percentages. plotting the standard curve on the semi logarithmic graph paper, placing the value of standards on $\mathrm{x}$-axis and corresponding absorbance value on Y-axis. The concentration of TAF.

Levels in the tested samples were estimated from the standard curve relation optical density versus TAF standards.

\subsection{Preparation of $L A B$ inoculums}

Lactobacillus acidophilus was originally obtained from Ch. Hansen's Lab.
(Denmark), and Bifidobacteriumlactis which obtained from Australian Research Center Australia, they were reactivated by three consecutive sub culturing on De Man Regosa \& Sharp medium (MRS) broth and agar at 37 ${ }^{\circ} \mathrm{C}$ for 24 hrs. The suspensions were centrifuged at $1.700 \mathrm{Xg}$ for 15 minutes. The supernatant was discarded, and the bacterial pellets were washed twice with phosphate buffered saline (PBS; PH 7.3, $0.01 \mathrm{M}$ ) and the concentration of Lactobacillus acidophilus and Bifidobacteriumlactis was adjusted to obtain desired inoculums level $10^{7} \mathrm{cfu} / \mathrm{ml}$ (Maha et al., 2015)

\subsection{Decontamination of total aflatoxins by} $L A B$ :

Fresh minced meat sample (200 gm) which contain known amount of TAF (4.212 ppb) that was estimated using ELISA was divided into two groups, each group inoculated with Lactobacillus acidophilus and Bifidobacteriumlactis in conc. of $10^{7} \mathrm{cfu} / \mathrm{g}$, separately. Then samples were examined for total aflatoxin residues at zero time and every 48 hrs using ELISA.

\section{RESULTS}

Table (1): Statistical analytical results (ppb) and acceptability of total aflatoxin residual levels in examined meat products $(n=25$ of each)

\begin{tabular}{|c|c|c|c|c|c|c|c|c|c|c|}
\hline \multirow[t]{2}{*}{ Meat products } & \multicolumn{2}{|c|}{$\begin{array}{l}\text { Positive } \\
\text { samples }\end{array}$} & \multirow[t]{2}{*}{ Min } & \multirow[t]{2}{*}{ Max } & \multirow[t]{2}{*}{$\begin{array}{l}\text { Mean } \pm \text { SE } \\
\text { ppb }\end{array}$} & \multirow[t]{2}{*}{$\begin{array}{l}\mathrm{Pl}^{*} \\
\mathrm{ppb}\end{array}$} & \multicolumn{2}{|c|}{$\begin{array}{l}\text { Accepted } \\
\text { Samples }\end{array}$} & \multicolumn{2}{|c|}{$\begin{array}{l}\text { Unaccepted } \\
\text { samples }\end{array}$} \\
\hline & No & $\%$ & & & & & No & $\%$ & No & $\%$ \\
\hline Burger & 16 & 64 & 0.1 & 3.1 & $0.73 \pm 0.15^{\text {(a) }}$ & 20 & 25 & 100 & 0 & 0 \\
\hline Sausage & 20 & 80 & 0.1 & 2.5 & $0.77 \pm 0.20^{(a)}$ & 20 & 25 & 100 & 0 & 0 \\
\hline Minced meat & 18 & 72 & 0.1 & 2.5 & $0.65 \pm 0.14^{(a)}$ & 20 & 25 & 100 & 0 & 0 \\
\hline Luncheon & 22 & 88 & 0.2 & 6.0 & $1.63 \pm 0.32^{(\mathrm{A})}$ & 20 & 25 & 100 & 0 & 0 \\
\hline
\end{tabular}


There were highly significance differences $(\mathrm{P}>0.01)$ between capital and small letters within the same coloum

N.B: P1* according to FDA (2000) and FAO (2004).

Table (2): Effect of different probiotics on reduction percentage of total aflatoxins in experimentally contaminated minced meat sample:

\begin{tabular}{lcccccccc} 
& \multicolumn{2}{c}{ Zero time } & \multicolumn{2}{c}{$2^{\text {nd }}$ day } & $4^{\text {th }}$ day & \multicolumn{2}{c}{$6^{\text {th }}$ day } \\
\cline { 2 - 8 } $\begin{array}{l}\text { Type of } \\
\text { probiotic }\end{array}$ & $\begin{array}{c}\text { Conc } \\
(\mathrm{pp})\end{array}$ & $\begin{array}{c}\text { Reduction } \\
\%\end{array}$ & $\begin{array}{c}\text { Conc } \\
(\mathrm{ppb})\end{array}$ & $\begin{array}{c}\text { Reduction } \\
\%\end{array}$ & $\begin{array}{c}\text { Conc } \\
(\mathrm{ppb})\end{array}$ & $\begin{array}{c}\text { Reduction } \\
\%\end{array}$ & $\begin{array}{c}\text { Conc } \\
(\mathrm{ppb})\end{array}$ & $\begin{array}{c}\text { Reduction } \\
\%\end{array}$ \\
\hline Group A & 4.212 & 0 & 2.991 & 29 & 2.11 & 50 & 0.505 & 88 \\
\hline Group B & 4.212 & 0 & 1.116 & 73.5 & 0.303 & 92.8 & 0.075 & 98.2 \\
\hline
\end{tabular}

Group A: Samples treated with Lactobacillus acidophilus.

Group B: samples treated with Bifidobacteriumlactis.

\section{DISCUSSION}

\section{1-Determination of aflatoxin residual levels in examined meat products}

Mycotoxins are fungal secondary metabolites that if ingested can cause a variety of adverse effects on both human and animal. Aflatoxins are carcinogenic compounds produced predominantly by certain strains of Aspergillus genus. They have immunosuppressive, mutagenic, teratogenic and carcinogenic effects, especially on the liver Morteza et al. (2013). Aflatoxin can enter the food supply by direct contamination which resulted from mould growth on the food, or indirectly through the use of contaminated ingredients in processed food or by feeding mouldy feed to food producing animals. Indirect contamination of food may be a problem in some area of the world where food is more highly processed Bahagt et al. (1999). Table and Fig. (1) showed that AFT residual levels in all examined meat product samples were within the permissible level of total aflatoxin residues (20 ppb) which has been specified by FDA (2000) and FAO (2004). Burger, sausage and minced meat samples contained lower level of aflatoxin residues as compared with luncheon samples (there was a highly significant difference $(\mathrm{P}>0.01)$. Mean total aflatoxin residual level was $0.73 \pm 0.15 \mathrm{ppb}$ in $16(64 \%)$ out of 25 examined burger samples. Nearly similar low aflatoxin B1 residual level in burger was recorded by El-Mossalami (2010) (0.41 ppb). Higher results were obtained by El-Shafei (2007) (40\% were contaminated with $14.89 \mathrm{ppb}$ ), Abd-Elghany and Sallam (2015) who found that all 25 examined burger samples (100\%) collected from Mansoura city were contaminated with (3.22 ppb) total aflatoxin (AFT), out of which, $40 \%$ were exceeded FAO, AFT permissible limit and Gehad et al. (2017) who found total aflatoxin average \pm SE, 4.17 \pm $0.66)$.

In this respect. Zohri et al. (2014) could detect 6 samples $(30 \%)$ contaminated with AFT; one sample $(6 \%)$ was contained $>100$ $\mathrm{ppb}$ and the remained 5 samples contained $<50$ ppb. Moreover, Maktabi et al. (2016) who found $3(6.3 \%)$ of burger samples were contaminated with $>1 \mu \mathrm{g} / \mathrm{kg}$ AFT. 
Table (1) shwoed that the mean aflatoxin residual level in examined sausage samples was $0.77 \pm 0.20 \mathrm{in} 20(80 \%)$ out of 25 examined sausage samples. Higher AFT residual levels were recorded by several investigators; Hassan and Ragheb (1996) \{6 samples (15\%) contained $1280 \mathrm{ppb}, 1(2.5 \%)$ contained $160 \mathrm{ppb}, 2(5 \%)$ contained $84 \mathrm{ppb}$ and 3 samples (7.5\%) contained $486 \mathrm{ppb}$ residual AFT, Brr et al. (2004) (35-50 ppb for AFB1 in all samples, 17-22 ppb AFB2, 45-50 ppb AFG1and 20-22 AFG2). Lower prevalence with high residual levels were recorded by Dalia (2012) (55\% with mean $15.22 \pm 3.40$ ppb AFT), Markov et al. (2013) (10\% contained $3.0 \mathrm{ppb}$ residual AFB1) and Maktabi et al. (2016) \{2 samples (4.9\%) were contaminated with $>1 \mu \mathrm{g} / \mathrm{kg}$ AFT . Lower prevalence of AFT was recorded by, Ismail et al. (2013) who could not detect AFB1 residues in examined sausage samples and Zohri et al. (2014) (10\%).

Regarding AFT residual levels in examined minced meat samples (Table 1 and Fig.1), mean ppb was $0.65 \pm 0.14$ where 18 (72\%) were positive. Higher results of AFT residual levels were recorded by El-Shafei (2007) (AFT detected with 8.52ppb in 20\% of examined samples) and Mohammed (2015) (B1, B2, G1 and G2 were $(3.62 \pm 0.88,3.40 \pm$ 0.82. $4.24 \pm 0.85$ and $2.83 \pm 0.60)$, respectively. Lower prevalence of AFT residual levels was recorded by Hassan et al. (1997) (16.6\%).

Results of AFT residual levels mentioned in Table and Fig. (1) revealed that mean AFT (ppb) in examined luncheon samples were $1.63 \pm 0.32$. Luncheon samples contained the highest prevalence $22(88 \%)$ as compared with other products. Nearly similar results for AFT residual level was recorded by Mohamed et al. (2014) (1.1 ppb) in Mansoura city, in addition, all samples had a lower AFT permissible residual level by FDA (2012), while the prevalence of samples contained
AFT obtained by the author was higher $(25 / 100 \%)$ than that recorded in the present study. Higher AFT residual levels were reported by several investigators; Ismail et al. (2013) (AFB1, B2, G1 and G2 were 3.71 $1.35,3.59 \pm 1.12,5.24 \pm 1.12$ and $6.77 \pm 1.49$ ppb, respectively) and Gehad et al. (2017) (5.44 $\pm 0.39 \mathrm{ppb})$. Lower prevalence with high AFT residual level was recorded by Khater (2004) (examined luncheon samples were contained aflatoxin B1 minimum 1.3, maximum 24.5 and average \pm SE, 10.4 \pm 5.1 ppb) and Dalia (2012) (25\%, contained $3.92 \pm$ $0.88 \mathrm{ppb}$ for AFT).

The production of mycotoxins in meat and meat products can be fostered by the presence of oxygen, temperatures between 4 and $40{ }^{\circ} \mathrm{C}$, $\mathrm{pH}$ values between 2.0 and 8.0 , a minimum aw of 0.80 , and a maximum salt concentration of $14 \%$ Ostry and Ruprich (2001). It seems that there is no relationship between the presence of toxogenic strains of moulds and mycotoxin contamination of meat samples, as it is not cleared whether aflatoxin was produced during meat processing or it was present before as a residual level in muscles Ismail and Zaki (1999).

4-2- Effect of different probiotics on the reduction of total aflatoxins (AFT) in naturally contaminated minced meat:

Food and feedstuff contamination with aflatoxins (AFTs) is a serious health problem for humans and animals, especially in developing countries (Ghazvini et al., 2016 and Silvia, 2007) Vinderola and |Ritieni (2015) revealed that Probiotics are live microorganisms which when administered in adequate amounts confer a health benefit on the host. They commonly belong to the genera Bifidobacterium and Lactobacillus, as they are the most acceptances by the international scientific community joint FAO/WHO working group (FAO/WHO, 2002). 
Table (2) explained using two groups of naturally contaminated minced meat samples with aflatoxins; the $1^{\text {st }}$ group (A) was inoculated with $7 \log _{10} \mathrm{cfu} / \mathrm{g}$ Lactobacillus acidophilus and the $2^{\text {nd }}$ group (B) was $\begin{array}{llll}\text { inoculated with } & 7 & \log _{10} \mathrm{cfu} / \mathrm{g}\end{array}$ Bifidobacteriumlactis.

The two groups were stored at $4^{\circ} \mathrm{C}$ and examined at zero time, 2, 4, 6 and 8 days of storage to determine the effect of used probiotics on the reduction of total aflatoxins. The obtained results revealed the following. At zero time, the concentrations of total aflatoxins remain constant with zero reduction $\%$ for both probiotics used in group A \& B. At the $2^{\text {nd }}$ day of storage, AFT was reduced by $29 \%$, recorded $2.991 \mathrm{ppb}$. For group (A), while group (B) recorded 1.116 AFT concentration with $73.5 \%$ reduction rate. At the $4^{\text {th }}$ day of storage, AFT concentration reduced to $2.11(50 \%)$ and $0.303(92.8 \%)$ in group A and B, respectively. At $6^{\text {th }}$ day of storage, AFT concentration recorded 0.505 with $88 \%$ reduction rate for group (A) and 0.075 (98.3\%) for group (B). from the obtained results, it could be concluded that Bifidobacteriumlactis found to be more effective in elimination of AFT from contaminated minced meat than Lactobacillus acidophilus.

Similar results were recorded by several investigators; El-Nezami et al. (1998) who found that probiotics had the ability to bind with aflatoxins B1 and removed it, Haskard et al. (2017) found that probiotics strains including $L$. rhamnosus GG and $L$. rhamnosusLC-705 were the most efficient strains in removing AFB1, with removal rates of $78.9 \%$ and $76.5 \%$, respectively, Soheret al. (2009) ( achieved 100\% complete inhibition of fungal growth and aflatoxin production by using cell free supernatants(CFS) from several Lactobacillus species and she also reported that $L$. acidophilus recorded the highest inhibitory effect on the germination of $A$. parasiticus.

Maha et al. (2015) reported complete elimination of aflatoxin M1 by adding $L$. acidophilus and $B$. lactis to naturally contaminated milk with 50.2 ppt after 3 days of cold storage at refrigerator.

In a study carried out by Ghazvini et al. (2016) found that LAB was able to reduce total aflatoxins and $B_{1}, B_{2}, G_{1}$ and $G_{2}$ fractions by more than $99 \%$. Moreover, LAB metabolites reduced the level of standard $\mathrm{AFB}_{1}, \mathrm{~B}_{2}, \mathrm{G}_{1}$ and $\mathrm{G}_{2}$ from $88.8 \%$ to $99.8 \%$ $(p \leq 0.05)$. Lower limit of aflatoxin B1 removal from contaminated food products than that of the present study was mentioned by Peltonen et al. (2001) observed that Lactobacillus and Bifidobacteria were able to remove $5.6 \%$ to $59.7 \%$ of AFB1, they added that, Bacterial binding of $\mathrm{AFB}_{1}$ by some probiotic strains was rapid, and more than $50 \%$ of $\mathrm{AFB}_{1}$ was bound throughout a 72-h incubation period and these findings further support the ability of specific strains of lactic acid bacteria to bind selected dietary contaminants.

Gratz et al. (2004) and Oatley et al. (2000) found that probiotics could bind significantly from $25 \%$ to $60 \%$ of added aflatoxins and made it unavailable for absorption in the intestinal tract. The authors suggested that there are reproducible strain differences in AFB1 binding capacity, Shahin (2007) observed that L. lactis and $S$. thermophiles could able to remove a greatest rate $(71 \%$ to $86.7 \%$ and $66.5 \%$ to $91.5 \%)$ of AFB1, respectively where asnon viable cells of L. lactis could remove $100 \%$ of the toxin. Kabak et al (2006) (37\%).Romina et al. (2011) reported that AFB1 binding ability of Lactobacillus acidophilus Po22 was $42.8 \pm$ 1.7, L. acidophilusPo7 was $34.6 \pm 1.6$ and $L$. acidophilus 24 was $32.6 \pm 2.0$., Haskardet al. (2017) (up to $71 \%$ ). 
Generally, the obtained results probiotics have the ability to make biological detoxification to aflatoxins as explained by Halasz et al. (2009) who revealed that biological detoxification of mycotoxins works mainly via two major processes, sorption and enzymatic degradation.

In fact, the potential presence of aflatoxins in animal diet is un avoidable, therefore a protection against aflatoxicosis is necessary, and the inclusion of microorganisms in the diet which able to remove AFB1 considered the most suitable alternative. The aflatoxinmicroorganism mostly probiotics interaction is a fast, reversible and strain specific process, it is a physical adsorption to the cell wall of the microorganism Romina et al. (2011).

\section{CONCLUSSION:}

From the obtained results, one can conclud that there should be greater attention for consumption of mould contaminated meat products. A strict control against contamination of meat products with mould and aflatoxins.

LAB is naturally associated with many foods and are well recognized for their bio preservative properties. This study showed the ability of Lactobacillus acidophilus and Bifidobacteriumlactis to reduce aflatoxin levels through production of several lowmolecular-weight antifungal metabolites, binding to the cell wall or combination of acidity and microbial competition. These antifungal LABS can be used in the food industry instead of chemical preservatives to produce organic foods. Furthermore, the excellent properties of LAB may preserve nutritional value of foods and delay spoilage. The future trends are to include beneficial probiotic microorganisms in a process of dietary detoxification of contaminated foods to constitute an approach for the decrease of the availability of aflatoxins in the human nutrition and animal feed. Due to their economic importance for the food industry and their health-related implications as probiotics safety assessment and risk analysis must be considered.

\section{REFERENCES}

Abd-Elghany, S. M. and Sallam, K. I. (2015): Rapid determination of total aflatoxins and ochratoxins a in meat products by immuno-affinity fluorimetry. Food Chemistry; 179:253-256.

Anonymous (2000): Veratox Software for Windows. Version 2,0, II. Technology Inc., Palm City, FL.

Bahagt, M. E. (1999): Mycotoxin Apotential universal everlasting threat, consumpersspective $5^{\text {th }}$ Sci. Cong. Egyptian Society for cattle Diseases 28 30: 22-35.

Brr, A. H.; Moustafa, N. Y. and Edris, A. M. (2004): Incidence of moulds and Aflatoxins in Some Meat Products. Benha Vet. Med. J., 15 (2): 65-75.

Dalié, D. K. D.; Deschamps, A. M. and Richard, F. (2010): Lactic acid bacteria Potential for control of mould growth and mycotoxins. A review Food Control; 21: 370-380.

Dalia, Y. Y. M. (2012): Toxicological aspects of moulds in meat products and giblets. Phd. Thesies, Meat Hygiene. Beni-Suef Univ. Egypt.

El-Mossalami, H. A. (2010): Occurrence of some mycotoxins residues in meat and meat products with studying the effect of different food processing methods on mycotoxin stability in meat samples. Assiut Vet. Med. J., 56 (125): 65-68.

El-Nezami,H.; Kankaanpaa,P.; Salminen, S. and Ahokas, J.(1998): Ability of dairy strains of lactic acid bacteria to bind a common food carcinogen, aflatoxin B1. 
Food \& Chemical Toxicology 36: 321326.

El-Shafei, H. M. (2007): Contamination of meat and meat products with fungi and mycotoxins Ph. D. Thesis- Fac. Vet. Med. Cairo Univ. Egypt.

Farber, P.; Brost, I; Adam, R. and Holzapfel, W. (2000): HPLC based method for the measurement of the reduction of aflatoxin $\mathrm{B} 1$ by bacterial cultures isolated from different African foods. Mycotoxin Res; 16: 141.

FAO, (2004): Worldwide regulations for mycotoxins in food and feed in 2003. FAO food and nutrition papers, Rome, Italy, 81.

FAO/WHO (2002): Guidelines for the evaluation of probiotics in food. Food and Agriculture Organization of the United Nations and World Health Organization Working Group Report.

FDA (2000): Guidance for Industry: Action levels for Poisonous or Deleterious substances in Human Food and Animal Feed, Center for Food Safety and Applied Nutrition, Food and Drug Adminstration, 5001 Campus Drive, College Park, MD 20740.

Gehad, N. M. Abdo; Nagwa, I. M. Khafaga; El- Hariri M. and Mohamed K. Refai(2017): Detection of fungi and total aflatoxinsin food addittives and some meat products by serological and molecular biological methods. J. Egyptian Vet. Med. Ass. 77(2): 153171.

Ghazvini, R. D.;Kouhsari, E.;Zibafar, E.;Hashemi, S. J.; Amini, A. and Niknejad, F. (2016): Antifungal Activity and Aflatoxin Degradation of BifidobacteriumBifidum and Lactobacillus Fermentum Against Toxigenic Aspergillus Parasiticus. Int J Food Microbiol. Open Microbiol J. 30:10:197-
Girary, B; Girgin, G.; Engin, A. B.; Aydin, S. and Shahin, G. (2007): Aflatoxin levels in wheat samples consumed in some regions of Turkey. Food Control, 18: 23-29.

Gratz, G.; Mykkanen, H.; Ouwehand, C.; Juvonen, R.; Salminen, S. and ElNezami, H. (2004): Intestinal mucus alters the ability of probiotic bacteria to bind aflatoxin B1 invitro. J. Appli. And Environ. Microbiol., 70(10): 63066308.

Halasz, A.; Lasztity, R; Abonyi, T. and Bata, A. (2009): Food Reviews International, 25: 284-298.

Hamidi, A.; Reza, M.; Emad, Y.; Vahid, B.; Ali, M.; Sajad, A.; Sara, S and Ebrahim, K., D. (2013): The aflatoxin B1 isolating potential of two lactic acid bacteria, Asian Pac. J. Trop. Biomed. 3(9): 732-736.

Haskard, C.A., El-Nezami, H.S.; Kankaanpaa, P.E.; Salminen, S. and Ahokas, J.T. (2017): Surface Binding of Aflatoxin $\mathrm{B}_{1}$ by Lactic Acid Bacteria. American Society for Microbiology, Appl. And Environ. Microbiol.83:(22)

Hassan, A. A. and Ragheb, R. R. (1996): Identification of some fungi and mycotoxins in sausage. Vet. Med. J. Giza, 44 (2): 215-220.

Hassan, A. A.; Hafez, H. A. and Asefa, A. E. (1997): Mycological examination of frozen meat, chickens and meat products. Zag. Vet. J., 25: 33-39.

Heinz, G. and Hautzinger, P. (2007): Meat Processing Technology. For Small-To Medium scale Producers. Food and Agriculture Organization of the United Nations Regional Office for Asia and the Pacific.

International Agency for Research on Cancer (IARC) (2002): Monograph on the evaluation of carcinogenic risk to human. Some traditional herbal 
medicines, some mycotoxins, naphthalene and styrene: Summary of data reported and evaluation (Vol. 82)

Ismail, M. A. and Zaky, Z. M. (1999): Evaluation of the mycological status of luncheon meat with special reference to aflatoxigenic moulds and aflatoxin residues. Mycopathologia; 146(3):147154.

Ismail, S. A.; Shehata, A. A.; El-Diasty, E. M. (2013): Microbiological quality of some meat products in local markets with special reference to mycotoxins. J. Global Veterinaria; 10(5):577-584.

Kabak, B.; Alan, D. and Var, I. (2006): Strategied to prevent Mycotoxin Contamination of Food and Animal Feed: A Review. Crit Rev Food SciNutr, 593-619.

Khater, D. F. (2004): Studies on microbial toxins in some vacuum-packed meat products Ph. D. Thesis- Fac. Vet. Med. Benha Univ. Egypt.

Maha, M. E.; Mahmoud, E; Nagwa, I. M. K and Mohamed, K. R. (2015): Studies on contamination of dairy products by aflatoxin M1 and its control by probiotics. J. Global Biosciences, 4(1), pp.1294-1312.

Maktabi, S.; Fazlara, A.; Ghorbanpoor, M.; Talayol, G. and Siavashi, M. (2016): Measurement and assessment of aflatoxin B1 and its producing molds in Iranian sausages and burgers. J. of Kermanshah University of Medical Sciences; 20(2):74-78.

Markov, K.; Pleadin, J.; Bevardi, M.; Vahcic, N.; Sokolic-Mihalak, D. and Frece, J. (2013): Natural occurrence of aflatoxin $\mathrm{B}<$ sub $>1</$ sub $>$, ochratoxin $A$ and citrinin in Croatian fermented meat products. Food Control; 34(2):312317.

Mohamed, M. M. E. (2015): Studies on mycotoxins in some meat products. $\mathrm{Ph}$.
D, Thesis Vet. Med. Sci. Food Control (Meat Hygiene), Fac. Of Vet. Med. Benha Univerisity.

Mohamed, N. H.; Atef, A. H.; Yasmine, H. T. and Sameh, F. A. (2014): Aflatoxin producing moulds and aflatoxin residues in meat and meat products in Egypt. Zag. Vet. J. 42 (3): 43-55.

Morteza, A. A.; Fatemeh (Elham), A.; Mahya, M. and Reza, K. D. (2013): Biological control of aflatoxins. European. J. of Experimental Biology, 3 (2): 162-166.

Oatley, J. T.; Matthew, D. R.; Ji, G. and Linz, J. E. (2000) Binding of Aflatoxin B1 to BifidobacteriaIn Vitro. Journal of Food Protection: Vol. 63(8):1133-1136.

Ostry, V. and Ruprich, J. (2001): Vyskytplisni $\mathrm{v}$ mase a masnychvyrobeich (II). Jaky je soucasnystav v CR. Maso, 12:17-21.

Peltonen, K.; El-Nezami, H.; Haskard, C.; Ahokasand. J. and Salminen, S. (2001): Aflatoxin B1binding by dairy strains of lactic acid bacteria and Bifidobacteria. Journal of Dairy Science. 84: 21522156.

Romina, P. P.; Dante, J. B.; Maria, R. A.; Lilia, C.; Ana,M. D. and Mario, A. S. (2011): Binding of Aflatoxin B1 to Lactic Acid Bacteria and Saccharomyces cerevisiae in vitro: A Useful Model to Determine the Most Efficient Microorganism, Aflatoxins Biochemistry and Molecular Biology, ISBN: 978-953-307-395-8, In Tech, 323:346.

Ross, R. P.; Morgan, S. and Hill, C. (2002): Preservation and fermentation: past, present and future. International J. Food Microbiol., 79: 3-16.

Sahar, N.; Arif, S.; Afzel, Q.; Ahmed, M.; Ara, J. and Chaudhry, Q. (2013): Impact of discoloration and picking practices of red chilies on aflatoxin levels, Park. J. Bot, 45(5):1169-1672.

Sara, H.A.;Vesa, J. and Hannu, J.K. (2015): 
Potential of lactic acid bacteria in aflatoxin risk mitigation. International Journal of Food Microbiol. ( 207): 87102.

Shahin, A. A. M. (2007): Removal of aflatoxin B1 from contaminated liquid media by dairy lactic acid bacteria. Int. J. of Agric Biol., 9 (1): 71-75.

Silvia, G. (2007): Aflatoxin binding by probiotics: Experimental studies on intestinal aflatoxin transport, metabolism and toxicity. Kuopio University Publications D. Medical Sciences 404, 85 p.

Soher, E. A.; Amal S. H. and Shaker M. E. (2009): INHIBITORY EFFECT OF SOME LactobacillusSPECIES ON ACTIVITY AND AFLATOXIN PRODUCTION BY
Aspergillusparasiticus. Assiut J. of Agric. Sci. 40(Special Issue) (35-56).

Stoloff, L.; Egmond, H.P. and Park, D. L. (1991): Rationales for the establishment of limits and regulations for mycotoxins. Food Addit. Contam, 8: 213-216.

Vinderola, G. and Ritieni, A. (2015): Role of Probiotics Against Mycotoxins and Their Deleterious Effects. J. of Food Res., 4(1): 1-12.

Zohri, A.A.; Moharram, A.M. and Refaie, R.R.S. (2014): Mycobiota contaminating beef burger and sausage with reference to their toxins and enzymes. J. Basic and Appli. Mycol., 5: 61- 